\title{
First record of Stiphodon annieae Keith \& Hadiaty, 2015 (Teleostei, Oxudercidae) from Sulawesi Island, Indonesia
}

\author{
Abdul Gani ${ }^{1}$, Nurjirana ${ }^{2}$, Achmad Afif Bakri ${ }^{3}$, Devita Tetra Adriany ${ }^{3}$, Erwin Wuniarto ${ }^{1}$, \\ Lady Diana Khartiono ${ }^{1}$, Dawam Heksa Satria ${ }^{1}$, Veryl Hasan ${ }^{4}$, Muh. Herjayanto ${ }^{5}$, \\ Andi Iqbal Burhanuddin ${ }^{2}$, Abigail Mary Moore ${ }^{6}$, Hirozumi Kobayashi ${ }^{7}$ \\ 1 Faculty of Fisheries, Muhammadiyah Luwuk Banggai University, Sulawesi Tengah, Indonesia •AG: abdulgani273085@gmail.com \\ (1) https://orcid.org/0000-0001-9730-4251・EW: erwinwun28@gmail.com (D https://orcid.org/0000-0002-7469-1137•LDK: \\ ladykhartiono23@gmail.com (1) https://orcid.org/0000-0003-2733-6156•DHS: heksdawam06@gmail.com (1) https://orcid.org/0000-0003- \\ 2113-0798 \\ 2 Faculty of Marine Science and Fisheries, Hasanuddin University, Sulawesi Selatan, Indonesia • N: nurjirana@gmail.com (1 https://orcid. \\ org/0000-0003-4801-1481 • AIB: iqbalburhanuddin@yahoo.com @ https://orcid.org/0000-0001-6770-7914 \\ 3 Fish Quarantine, Quality Control and Fisheries Product Safety Station, Sulawesi Tengah, Indonesia • AAB: 4chmad4fif@gmail.com \\ (1) https://orcid.org/0000-0002-3021-0370•DTA: devita_adriany@yahoo.com (D https://orcid.org/0000-0001-8809-6286 \\ 4 Fish Health Management and Aquaculture, Faculty of Fisheries and Marine, Airlangga University, Jawa Timur, Indonesia • veryl.hasan@fpk \\ unair.ac.id \\ (D) https://orcid.org/0000-0001-5457-9335 \\ 5 Department of Fisheries, Faculty of Agriculture, University of Sultan Ageng Tirtayasa, Banten, Indonesia • herjayanto@untirta.ac.id \\ (D) https://orcid.org/0000-0002-6121-3523 \\ 6 Graduate School, Hasanuddin University, Sulawesi Selatan, Indonesia • abigail@pasca.unhas.ac.id (D https://orcid.org/0000-0002-4122-3740 \\ 7 Tropical Biosphere Research Center, University of the Ryukyus, Okinawa, Japan • acheilognathus5884@gmail.com (1) https://orcid.org/0000- \\ 0003-0718-5637 \\ * Corresponding author
}

\begin{abstract}
The recently described Stiphodon annieae (Keith \& Hadiaty, 2015) was thought to be endemic to Halmahera Island, Indonesia. However, from August 2019 to January 2020, we collected several specimens during field trips to the Soho, Simpong, and Uso rivers in Luwuk Banggai, Central Sulawesi, Indonesia. We describe specimens collected in the Soho River and discuss the ichthyofauna of Luwuk Banggai. This is the first report of S. annieae from Sulawesi. Our records represent a range extension of approximately 500-600 km west of this species' type locality on the island of Halmahera.
\end{abstract}

\section{Keywords}

Freshwater goby, Luwuk Banggai, range extension, Sicydiinae, Wallacea

Academic editor: Valter Azevedo-Santos | Received 31 July 2020 | Accepted 3 February 2021 | Published 22 February 2021

Citation: Gani A, Nurjirana, Bakri AA, Adriany DT, Wuniarto E, Khartiono LD, Satria DH, Veryl Hasan, Herjayanto M, Burhanuddin AI, Moore AM, Kobayashi H(2021) First record of Stiphodon annieae Keith \& Hadiaty, 2015 (Teleostei, Oxudercidae) from Sulawesi Island, Indonesia. Check List 17 (1) 261-267. https://doi.org/10.15560/17.1.261 


\section{Introduction}

Sulawesi, one of the four main islands in the Indonesian Archipelago, is located in the Wallacea region (Whitten et al. 1987). Sulawesi is renowned for its freshwater fish biodiversity, which includes a high proportion of endemic species (Whitten et al. 1987; Kottelat et al. 1993; Hadiaty 2018). Currently, three orders, six families, and 71 species of freshwater fish are known to be endemic to Sulawesi (Miesen et al. 2016; Hadiaty 2018; Mandagi et al. 2018; Kraemer et al. 2019; Kobayashi et al. 2020). Hadiaty and Sauri (2017) discussed the characteristics of the Indonesian freshwater fish fauna and mentioned that the ichthyofauna of western Indonesia is dominated by the order Cypriniformes, while that of eastern Indonesia, including Sulawesi, is dominated by Gobiiformes. While 44\% of Sulawesian inland fish species are obligate freshwater fishes (Adrianichthyidae, Telmatherinidae and several limnetic gobies), the remainder are euryhaline and/or amphi-, ana-, or diadromous (Miesen et al. 2016) and are therefore presumed to have a greater capability for dispersal.

Approximately $23 \%$ of the freshwater fish fauna of Sulawesi belong to the order Gobiiformes, with at least 16 endemic species of this order inhabiting lakes and rivers (Kottelat et al. 1993; Larson 2001; Hoese et al. 2015; Miesen et al. 2016; Hadiaty 2018). Thirty-six species of Gobiiformes are thought to be diadromous based on their widespread distributions (Keith 2003; Miesen et al. 2016). Recently, a series of discoveries have been made regarding the distribution of riverine and diadromous gobies in the tropical zone (e.g., Maeda and Tan 2013; Tweedley et al. 2013; Keith et al. 2014; Gani et al. 2019); nonetheless, the precise distribution of many species is still poorly known. It is likely that additional studies of the fish biodiversity of Sulawesi, in particular riverine ichthyofauna, will reveal more "widespread gobies".

The Sicydiinae, a subfamily of the gobiid family Oxudercidae, are a highly diverse group of fishes widely distributed over the tropics (Ebner et al. 2011). Many species in this group have an amphidromous life history in which larvae live in the ocean (Keith 2003). Many such species disperse during this oceanic phase (e.g., Watanabe et al. 2006; Iida et al. 2013; Lord et al. 2015). Within this group, the geographic distribution of species is known to differ considerably; some are widespread and others have been found only from one island (Keith et al. 2015). The factors affecting geographic distribution are still poorly understood.

A remarkable sicydiine goby, Stiphodon annieae Keith \& Hadiaty, 2015 was described from Halmahera Island, eastern Indonesia (Keith and Hadiaty 2015; Fig 1). Known only from and endemic to this island, information about $S$. annieae is limited. This species is known only from two male specimens from the type locality on

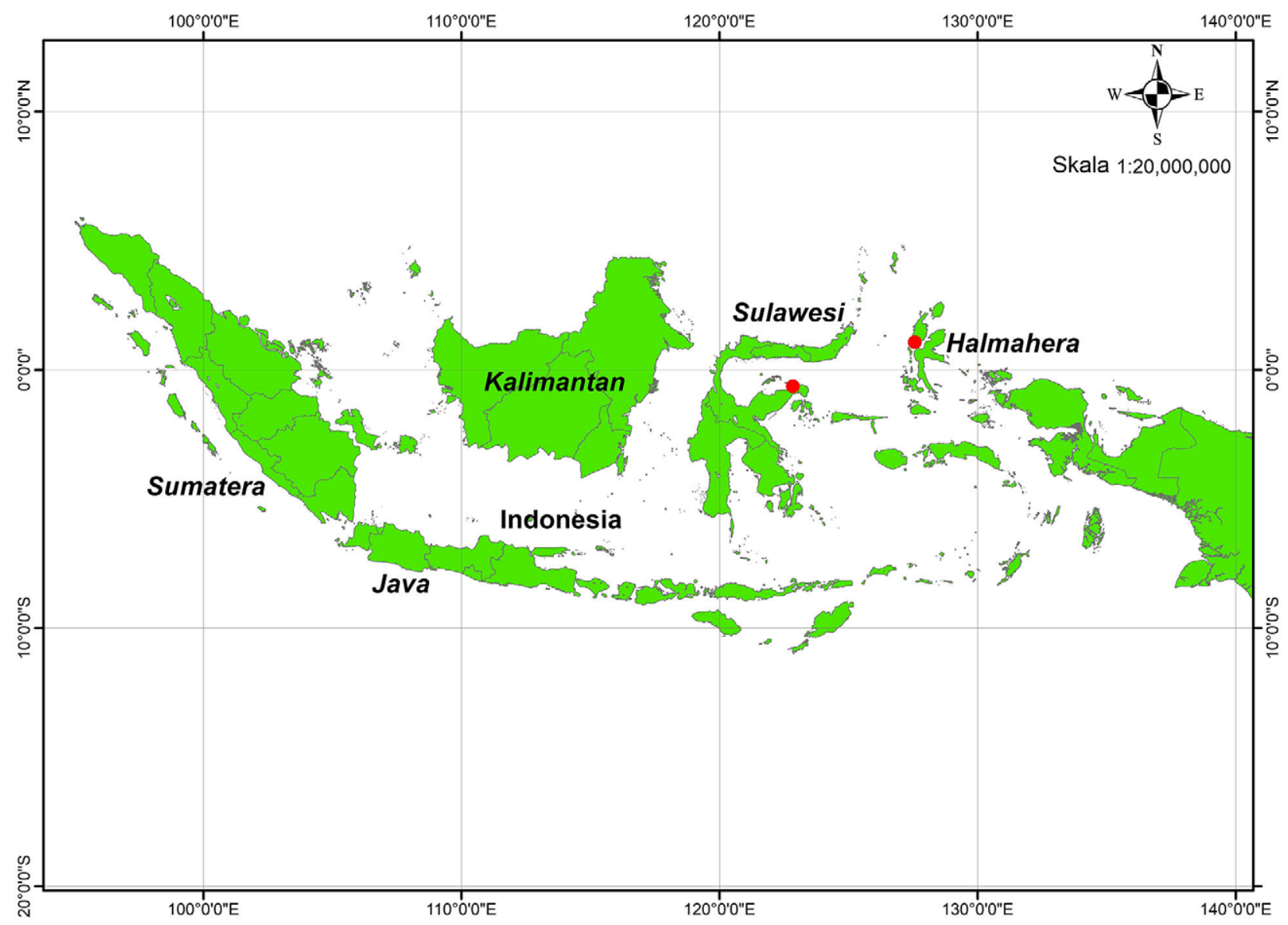

Figure 1. Map of Indonesia showing the recorded localities of Stiphodon annieae: the type locality on Halmahera (Keith and Hadiaty 2015) and the new record in Luwuk Banggai, Sulawesi. 
the island of Halmahera (Keith and Hadiaty 2015; Keith et al. 2015). Stiphodon annieae has not yet been evaluated using International Union for the Conservation of Nature criteria (IUCN 2020).

From August 2019 to January 2020, while exploring sicydiine assemblages in the Luwuk Banggai region on the eastern side of Sulawesi Island, Indonesia, we collected 23 specimens of $S$. annieae (Fig. 2) from three coastal streams. These specimens represent the first records of $S$. annieae from Sulawesi and a significant range extension by approximately $500-600 \mathrm{~km}$ west of the type locality (Fig. 1).

\section{Methods}

Individuals of $S$. annieae and comparative materials were

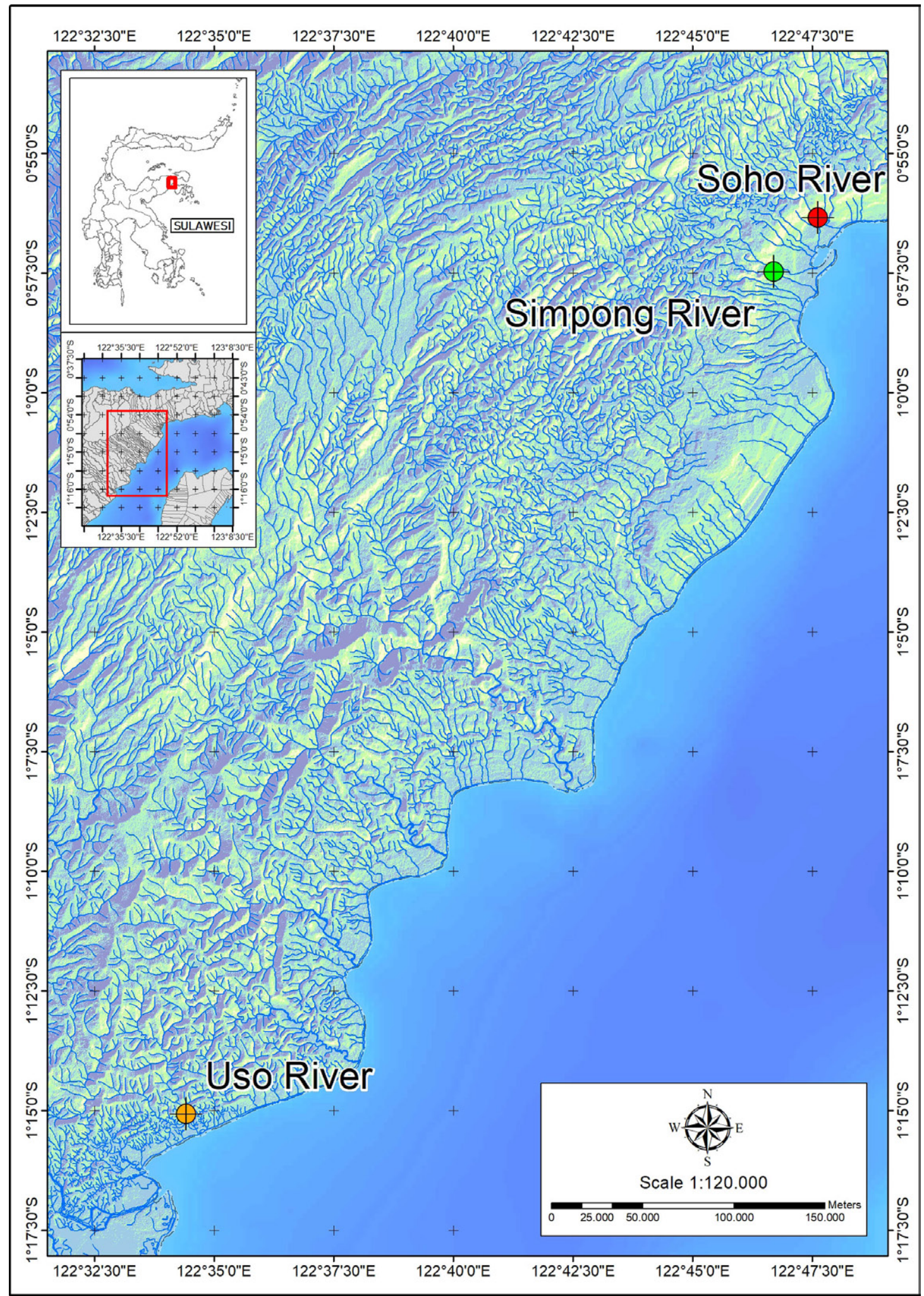

Figure 2. Map of the Luwuk Banggai region in Central Sulawesi showing the locations of the new records of Stiphodon annieae. The red, green and, orange symbols indicate the Soho, Simpong, and Uso rivers, respectively. 

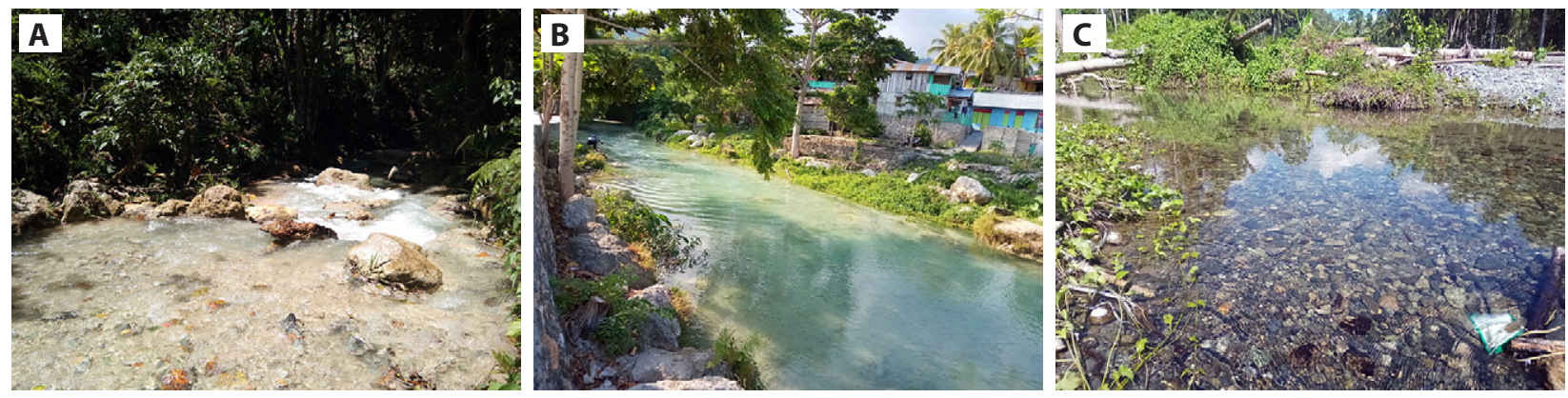

Figure 3. Habitat of Stiphodon annieae in Luwuk Banggai, Central Sulawesi. A. Soho River. B. Simpong River. C. Uso River.

collected using a beach seine. The specimens were collected from the middle reaches of the Soho River $\left(00^{\circ}\right.$ $\left.56^{\prime} 20^{\prime \prime} \mathrm{S}, 122^{\circ} 47^{\prime} 37^{\prime \prime} \mathrm{E}\right)$, the middle and upper reaches of the Simpong River $\left(00^{\circ} 57^{\prime} 28^{\prime \prime} \mathrm{S}, 122^{\circ} 46^{\prime} 42^{\prime \prime} \mathrm{E}\right)$, and the middle reaches of the Uso River $\left(01^{\circ} 15^{\prime} 04^{\prime \prime} \mathrm{S}, 122^{\circ}\right.$ $34^{\prime} 25^{\prime \prime} \mathrm{E}$ ) (Figs. 3, 4A-C). We collected 23 individuals in total. The collected specimens were euthanized with MS222, fixed in 3-10\% formalin, and then transferred to $70 \%$ ethanol for storage. These specimens were deposited in the laboratory of the Fish Quarantine Station of Luwuk Banggai, Luwuk (FCLB), the Marine Science and Fisheries Faculty, University of Hasanuddin, Makassar (MSFUH), the National Museum of Nature and Technology, Tokyo (NSMT), and the Museum Zoologicum Bogoriense, Cibinon (MZB). Identification of the specimens followed Larson (2010), Maeda and Tan (2013), Keith and Hadiaty (2015), and Keith et al. (2015).

Measurements of morphometric characters and meristic counts were obtained from the left side of each specimen collected from the Soho River. Morphometric measurements were taken from point to point using digital callipers with a precision of $0.1 \mathrm{~mm}$. Measurements were reported as a percentage of the standard length (SL) giving the range with the mean value in brackets. Measurements and counts basically follow Keith and Hadiaty (2015); however, measurements not given by Keith and Hadiaty (2015) follow Maeda and Palla (2015). Fin rays and spines, as well as scales, were counted directly under a stereomicroscope (Leica MZ6). Meristic counts were also reported as a range, with mean values in brackets.

\section{Results}

\section{Stiphodon annieae Keith \& Hadiaty, 2015}

Figure 4; Table 1

New records. INDONESIA - Central Sulawesi • Banggai District, Luwuk, middle reaches of the Soho River; $00^{\circ}$ 56'20"S, 12247'37"E; 2.IX.2019; A. Gani, A.A. Bakri and D.T. Adriany leg.; 1 ō, SL $21.5 \mathrm{~mm}$, FCLB 088/skilb/ sp.i/IX/2019 - same locality as the preceding; 18.VIII. 2019; H. Kobayashi, A. Gani, E. Wuniarto and D.H. Satria leg.; 4 đo, 22.3-25.0 mm SL, MZB 25321-25322 and NSMT-P 139835-139836 • Central Sulawesi, Banggai District, Uso River; $01^{\circ} 15^{\prime} 04^{\prime \prime} \mathrm{S}, 122^{\circ} 34^{\prime} 25^{\prime \prime} \mathrm{E}$; 25.I.2020; Nurjirana, A.I. Burhanuddin, E. Wuniarto and A. Gani leg.; 9 ô, 20.8-21.8 mm SL, MSFUH 1852-1860 • Central Sulawesi, Banggai District, Luwuk, Simpong River; $00^{\circ} 57^{\prime} 28^{\prime \prime} \mathrm{S}, 122^{\circ} 46^{\prime} 42^{\prime \prime} \mathrm{E}$; 24/I/2020; Nurjirana, A.I. Burhanuddin, E. Wuniarto and A. Gani leg.; 9 Ĵ, 21.2-21.8 mm SL, MSFUH 1843-1851.

Identification. The morphological and meristic characters of the specimens collected are provided in Table 1. All specimens collected in the Soho, Uso, and Simpong rivers were identified as males by several specific characters which include: absence of scales on the head, nape, breast, belly, and pectoral base; long head and jaw; pelvic disc adhering to the belly but only between the fifth rays, with a strong fleshy frenum between the spines; bright red flanks, with many blue spots on the dorsal part of the body, from the first dorsal fin to the caudal region; a greenish line from below the eye to the pectoral fin; bright red dorsal fin with black spots; distal blue line on the second dorsal fin; caudal fin bright red, with half blue

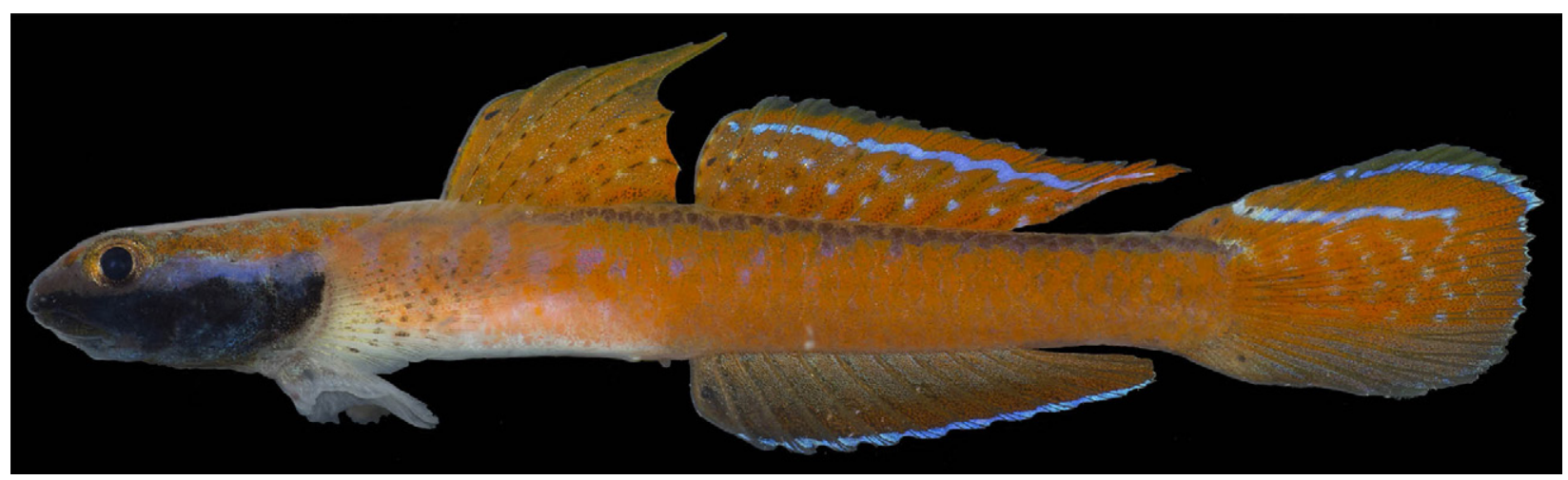

Figure 4. Stiphodon annieae, NSMT-P 139836 (male, 24.0 mm SL) immediately after fixation. 
Table 1. Morphometric and meristic characters of Stiphodon annieae.

\begin{tabular}{|c|c|c|}
\hline & $\begin{array}{l}\text { Soho River, } \\
\text { Sulawesi } \\
\text { males, } n=4 \\
\text { (this study) }\end{array}$ & $\begin{array}{c}\text { Halmahera } \\
\text { males, } n=2 \\
\text { (Keith and Hadiaty } \\
\text { 2014) }\end{array}$ \\
\hline Standard length (mm) & $22.3-25.0$ & $21.5-22.7$ \\
\hline \multicolumn{3}{|l|}{$\begin{array}{l}\text { Morphometric characters (in \% } \\
\text { of SL) }\end{array}$} \\
\hline Head length & $22.8-23.8$ & $25-26$ \\
\hline Snout length & $7.2-8.1$ & - \\
\hline Eye diameter & $5.2-6.6$ & - \\
\hline Postorbital length of head & $11.6-12.1$ & - \\
\hline Upper-jaw length & $9.1-9.6$ & $10-12$ \\
\hline Body depth at pelvic fin origin & $12.0-14.3$ & - \\
\hline Body depth at anal fin origin & $12.8-14.7$ & - \\
\hline Depth of caudal peduncle & $9.5-12.6$ & $7-9$ \\
\hline $\begin{array}{l}\text { Length of caudal peduncle from anal } \\
\text { fin base }\end{array}$ & $19.2-20.6$ & $12-13$ \\
\hline Predorsal length & $33.6-36.8$ & $35-37$ \\
\hline Length of first dorsal fin base & $17.8-21.0$ & - \\
\hline Length of first dorsal fin & $23.7-30.9$ & - \\
\hline $\begin{array}{l}\text { Length of longest spine of first } \\
\text { dorsal fin }\end{array}$ & $20.4-27.8$ & - \\
\hline $\begin{array}{l}\text { Interval between first and second } \\
\text { dorsal fin bases }\end{array}$ & $0.8-1.7$ & - \\
\hline Length of second dorsal fin base & $23.2-27.1$ & - \\
\hline Length of second dorsal fin & $38.1-43.5$ & $30-32$ \\
\hline Preanal fin length & $54.4-57.7$ & - \\
\hline Length of anal fin base & $26.5-28.4$ & - \\
\hline Length of anal fin & $35.2-39.9$ & $30-32$ \\
\hline Length between anus to anal fin base & $3.6-4.2$ & - \\
\hline Length of longest ray of pectoral fin & $22.4-23.8$ & - \\
\hline Length of caudal fin & $26.4-26.6$ & $19-23$ \\
\hline Length of pelvic fin & $14.0-16.1$ & - \\
\hline \multicolumn{3}{|l|}{ Meristic counts } \\
\hline Dorsal fin rays & $\mathrm{VI}+\mathrm{I}, 9$ & $\mathrm{VI}+\mathrm{I}, 9$ \\
\hline Anal fin rays & $\mathrm{I}, 10$ & $\mathrm{I}, 10$ \\
\hline Pectoral fin rays & $16-17$ & 14 \\
\hline Scales in lateral series & $18-19$ & $18-19$ \\
\hline Scales in transverse back series & $8-9$ & 9 \\
\hline Scales in transverse forward series & $8-9$ & $6-7$ \\
\hline Scales in predorsal midline & 0 & 0 \\
\hline
\end{tabular}

lines along the margin and in the uppermost part; hyaline pectoral fins with a black patch at the base; whitish belly.

\section{Discussion}

Dispersal abilities of amphidromous fishes vary among species and influence distribution patterns (e.g., Kondo et al. 2013; Teichert et al. 2016), but accurate knowledge of the distribution of amphidromous fishes is important, including for estimating their respective dispersal abilities. A study by Tweedley et al. (2013) on the riverine fish diversity of Buton and Kabaena islands off the southeastern peninsula of the Sulawesi mainland, found an ichthyofauna dominated by Gobiidae with just one Sulawesi endemic species. Tweedley et al. (2013) posited that species radiations and, hence, endemism in Sulawesi were concentrated in lacustrine environments, with most riverine species, and in particular the Gobiidae, having a wider distribution due to their amphidromous life cycle.

Species of Sicydiinae are known to vary in their geographic distribution, and Stiphodon annieae has been considered to have one of the narrowest distributions within its genus. Until now, S. annieae was known only from Halmahera, the type locality (Keith et al. 2015). Such a limited distribution could be due to extremely low ability for dispersal or an adaptation to a fully riverine habitat with shortened larval stage. We discovered $S$. annieae in three unconnected rivers (Fig. 3) in Sulawesi, approximately 500-600 km west of Halmahera (Fig. 1). The mouths of the Soho and Simpong rivers enter the sea less than $3 \mathrm{~km}$ apart; the lower reaches of these rivers run through the northern and southern suburbs of Luwuk City, respectively. The mouth of the Uso River is approximately $60 \mathrm{~km}$ southwest down the coast from Luwuk.

The range extension documented here suggests that $S$. annieae has the ability to disperse across seaways, as is the case for many other members of the genus Stiphodon (e.g., Lord et al. 2015; Maeda et al. 2015). It also opens up the possibility that other gobiid species, such as Lentipes adelphizonus Watson \& Kottelat, 2006, another species believed to be endemic to Halmahera, may occur in other areas. We believe that it is likely that the distribution range of $S$. annieae is restricted and patchy because we did not find this species during our previous surveys in northern, southeastern, and western Sulawesi (Miesen et al. 2016; Kobayashi unpublished data). To clarify the factors determining the narrow geographic distribution of this species, additional research is needed on its life cycle and ecology. For example, an otolith microstructure analysis, similar to that conducted for three Pacific Sicydiinae (Lord et al. 2010), could estimate the pelagic larval duration.

We identified our specimens as $S$. annieae based on colour pattern and morphological features of males. However, the number of pectoral-fin rays in the specimens from the Soho River was greater than in the type series; fish from the Soho River presented 16 or 17 rays while type material from Halmahera had 14 rays (Keith et al. 2015). Some other morphological traits also differed between these two localities, but only a small number of specimens of $S$. annieae are available for study. These differences could be an artefact of having only two specimens in the type series, or these may indicate divergence, with possible cryptic species involved. These questions might be answered by studying the genetic differentiation between populations. We recommend a combined morphological and genetic population analysis based on more individuals to determine the evolutionary relationship between the two populations.

We also collected female Stiphodon specimens, including several different morphotypes, from the same rivers as the males of $S$. annieae. These samples may include females of $S$. annieae, S. semoni Weber, 1895, and S. surrufus Watson \& Kottelat, 1995, but their identification is still pending. In the original description of $S$. annieae, Keith and Hadiaty (2015) had no information 
on females of this species. The identification of female Stiphodon is relatively difficult, as this genus and other sicydiine genera usually exhibit sexual dimorphism in several meristic traits (Keith et al. 2015). Nevertheless, it was previously thought that $S$. annieae and S. semoni, which are sympatric in Sulawesi, could be distinguished by the number of pectoral-fin rays, a trait that does not allow for sexual dimorphism (14 in $S$. annieae vs. 15 in $S$. semoni; Maeda and Tan 2013). However, with the new records and range extension of $S$. annieae in our study, and considering the possibility that both species may be amphidromous and dispersive, we cannot morphologically determine the female of $S$. annieae at this time. Thus, more comprehensive studies on the females of this genus are needed. These should include a description of females of $S$. annieae based on careful survey work backed by identification based on molecular biology methods such as DNA barcoding (Hubert et al. 2016). Well-supported reference sequences of commonly used molecular markers would enable the use of other molecular methods to assist in determining the distribution of $S$. annieae and related species, such as the use of environmental DNA (eDNA) and metabarcoding (Hubert et al. 2016; Lim et al. 2016; Gillet et al. 2018).

Luwuk Banggai, the site of this study, is one of the regions along the eastern coast of Sulawesi where many streams flow into the sea. Gani et al. (2020) recorded 17 species of Gobiiformes from these streams, including a first record from Sulawesi (Sicyopus discordipinnis Watson, 1995) and a range extension (Lentipes mekonggaensis Keith \& Hadiaty, 2015) from the Luwuk area, which together with the current study indicates a high diversity of Gobiiformes in the area. During this survey, we also recorded, for the first time in the Luwuk area, two other species from the Soho River: Stiphodon surrufus and Redigobius oyensi (de Beaufort, 1913). In addition, Gani et al. (2019) recorded Sicyopus discordipinnis Watson, 1995 from the Koyoan River in Banggai District; this species was previously known only from Papua New Guinea and Australia (Ebner et al. 2011; Keith et al. 2015). These findings further highlight the diversity of the gobiid ichthyofauna in the area and the need for more widespread and intensive sampling.

Our discovery of a species in common between Sulawesi and Halmahera islands highlights the complexity and diversity of this region's riverine ichthyofauna, even though there is a dearth of endemic freshwater fishes in this fauna. Freshwater biodiversity is both important and under threat (Dudgeon et al. 2006). We anticipate that continued investigation of the riverine ichthyofauna in Luwuk Banggai and surrounding areas will provide important information, not only for the conservation and sustainable use of these fishes, but also regarding the distribution pattern of amphidromous fishes and the mechanisms determining the formation of these patterns.

\section{Acknowledgements}

We thank Sutrisno K. Djawa, the Rector of Muhammadiyah Luwuk Banggai University, Moh. Ikbal Adam, Jusmanto, Monicha Indrasari Bungalim, Rauf, Bahri, Paju and the Student Executive Board organization (BEM) of the Faculty of Fisheries, Muhammadiyah Luwuk Banggai University, and Ekspedisi Riset Akuatika (ERA) Indonesia for support during our fieldwork. We are grateful to D.F. Mokodongan (Halu Oleo University) for his valuable comments and suggestions for our manuscript and to Rustam and Enjang Tri Budianto for assistance with the maps in Figures 1 and 2. We also thank I.V. Utama (MZB) and M. Nakae (NSMT) for the registration of our specimens in museum collections. This study was partially supported by the Grant-in-Aid for Scientific Research from the Ministry of Education, Culture, Sports, Science and Technology, Japan to H.K. (19J22686).

\section{Authors' Contributions}

AG, HK, N, and AIB conceived the study. All authors except AMM collected the samples in the field. AG, AAB, DHS, N, and HK identified the species. HK, AG, N, and $\mathrm{AAB}$ made measurements. $\mathrm{HK}, \mathrm{AG}$, and $\mathrm{N}$ took and edited the photograph of the specimen. HK, AG, AMM and $\mathrm{N}$ and wrote the manuscript. $\mathrm{AG}$ and all authors reviewed, finalized, and approved the manuscript.

\section{References}

Dudgeon D, Arthington AH, Gessner MO, Kawabata ZI, Knowler DJ, Lévêque C, Naiman RJ, Prieur-Richard AH, Soto D, Stiassny MLJ, Sullivan CA (2006) Freshwater biodiversity: Importance, threats, status and conservation challenges. Biological Reviews of the Cambridge Philosophical Society 81 (2): 163-182. https://doi. org/10.1017/S1464793105006950

Ebner BC, Thuesen PA, Larson HK, Keith P (2011) A review of distribution, field observations and precautionary conservation requirements for sicydiine gobies in Australia. Cybium 35 (4): $397-$ 414. https://doi.org/10.26028/cybium/2011-354-013

Gani A, Bakri AA, Adriany DT, Nurjirana, Herjayanto M, Bungalim IM, Ndobe S, Burhanuddin AI (2019) Identification of freshwater goby species from the Biak and Koyoan Rivers, Luwuk Banggai, Central Sulawesi. Jurnal Ilmu Kelautan Spermonde 5 (2): 57-60. https://doi.org/10.20956/jiks.v5i2.8931

Gani A, Wuniarto E, Khartiono LD, Srinurmahningsi, Mutalib Y, Nurjirana, Herjayanto M, Satria DH, Adam MI, Jusmanto, Bungalim MI, Adriany DT, Bakri AA, Subarkah M, Burhanuddin AI (2020) A note on Gobiidae from some rivers in Luwuk Banggai, Central Sulawesi, Indonesia. IOP Conference Series: Earth and Environmental Science 473: 01204. https://doi.org/10.1088/1755-13 15/473/1/012054

Gillet B, Cottet M, Destanque T, Kue K, Descioux S, Chanudet V, Hughes S (2018) Direct fishing and eDNA metabarcoding for biomonitoring during a 3-year survey significantly improves number of fish detected around a South East Asian reservoir. PLoS ONE 13 (12): e0208592. https://doi.org/10.1017/S1464793105006950

Hadiaty RK, Sauri S (2017) Freshwater fish of Enggano Island, Indonesia. Jurnal Iktiologi Indonesia 17 (3): 273-287. https://doi.org/10. 32491/jii.v17i3.365

Hadiaty RK (2018) Taxonomical status of endemic freshwater ich- 
thyofauna of Sulawesi. Jurnal Iktiologi Indonesia 18 (2): 175-190. https://doi.org/10.32491/jii.v18i2.428

Hoese DF, Hadiaty RK, Herder F (2015) Review of the dwarf Glossogobius lacking head pores from the Malili Lakes, Sulawesi, with a discussion of the definition of the genus. Raffles Bulletin of Zoology 63: 14-26.

Hubert N, Kadarusman, Wibowo A, Busson F, Caruso D, Sulandari S, Nafiqoh N, Pouyaud L, Rüber L, Avarre J-C, Herder F, Hanner R, Keith P, Hadiaty RK (2016) DNA Barcoding Indonesian freshwater fishes: challenges and prospects. DNA Barcodes 3 (1): 144169. https://doi.org/10.1515/dna-2015-0018

Iida M, Watanabe S, Tsukamoto K (2013) Riverine life history of the amphidromous goby Sicyopterus japonicus (Gobiidae: Sicydiinae) in the Ota River, Wakayama, Japan. Environmental Biology of Fishes 96 (5): 645-660. https://doi.org/10.1007/s10641-012-0055-9

IUCN (2020) The IUCN Red List of Threatened Species. Version 2020 2. https://www.iucnredlist.org/search?query=Stiphodon\&search Type=species. Accessed on: 2020-10-30.

Keith P (2003) Biology and ecology of amphidromous Gobiidae of the Indo-Pacific and Caribbean regions. Journal of Fish Biology 63: 831-847. https://doi.org/10.1046/j.1095-8649.2003.00197.x

Keith P, Hadiaty RK (2015) Stiphodon annieae, a new species of freshwater goby from Indonesia (Gobiidae). Cybium 38 (4): 267-272. https://doi.org/10.26028/cybium/2014-384-004

Keith P, Hadiaty R, Hubert N, Busson F, Lord C (2014) Three new species of Lentipes from Indonesia (Gobiidae). Cybium 38 (2): 133 146. https://doi.org/10.26028/cybium/2014-382-004

Keith P, Lord C, Maeda K (2015) Indo-Pacific sicydiine gobies: biodiversity, life traits and conservation. Société Française d'Ichtyologie, Paris, France, 256 pp.

Kraemer J, Hadiaty RK, Herder F (2019) Nomorhamphus versicolor, a new species of blunt-nosed halfbeak from a tributary of the Palu River, Sulawesi Tengah (Teleostei: Zenarchopteridae). Ichthyological Exploration of Freshwaters IEF-1105: 1-8. https://doi org/10.23788/IEF-1105

Kobayashi H, Masengi KWA, Yamahira K (2020) A new "beakless" halfbeak of the genus Nomorhamphus from Sulawesi (Teleostei: Zenarchopteridae). Copeia 108 (3): 522-531. https://doi.org/ 10.1643/CI-19-313

Kondo M, Maeda K, Hirashima K, Tachihara K (2013) Comparative larval development of three amphidromous Rhinogobius species, making reference to their habitat preferences and migration biology. Marine and Freshwater Research 64 (3): 249-266. https://doi org/10.1071/MF12234

Kottelat M, Whitten AJ, Kartikasari SN, Wirjoatmodjo S (1993) Freshwater fishes of western Indonesia and Sulawesi. Periplus Editions, Jakarta, Indonesia. 293 pp

Larson H (2001) A revision of the gobiid fish genus Mugilogobius (Teleostei: Gobioidei), and its systematic placement. Records of the Western Australian Museum Supplement 62: 1-233. https://doi org/10.18195/issn.0313-122x.62.2001.001-233

Larson H (2010) A review of the gobiid fish genus Redigobius (Teleostei: Gobionellinae), with descriptions of two new species. Ichthyological Exploration of Freshwaters 21 (2): 123-191.
Lim NKM, Tay YC, Tan JWT, Kwik JTB, Baloğlu B, Meier R, Yeo DCJ (2016) Next-generation freshwater bioassessment: eDNA metabarcoding with a conserved metazoan primer reveals species-rich and reservoir-specific communities. Royal Society Open Science 3: 160635. https://doi.org/10.1098/rsos.160635

Lord C, Brun C, Hautecœur M, Keith P (2010) Insights on endemism: Comparison of the duration of the marine larval phase estimated by otolith microstructural analysis of three amphidromous Sicyopterus species (Gobioidei: Sicydiinae) from Vanuatu and New Caledonia. Ecology of Freshwater Fish 19 (1): 26-38. https://doi. org $/ 10.1111 / \mathrm{j} .1600-0633.2009 .00386 . x$

Lord C, Maeda K, Keith P, Watanabe S (2015) Population structure of the Asian amphidromous Sicydiinae goby, Stiphodon percnopterygionus with comments on larval dispersal in the northwest $\mathrm{Pa}$ cific Ocean. Vie et Milieu—Life and Environment 65 (2): 63-71.

Maeda K, Tan HH (2013) Review of Stiphodon (Gobiidae: Sicydiinae) from western Sumatra, with description of a new species. Raffles Bulletin of Zoology 61 (2): 749-761.

Maeda K, Palla HP (2015) A new species of the genus Stiphodon from Palawan, Philippines (Gobiidae: Sicydiinae). Zootaxa 4018 (3): 381-395. https://doi.org/10.11646/zootaxa.4018.3.3

Maeda K., Tran HD, Tan HH (2015) Discovery of a substantial continental population of the subfamily Sicydiinae (Gobioidei: Gobiidae) from Vietnam: taxonomic revision of the genus Stiphodon from the western South China Sea. Raffles Bulletin of Zoology 63: $246-258$.

Mandagi IF, Mokodongan DF, Tanaka R, Yamahira K (2018) A new riverine ricefish of the genus Oryzias (Beloniformes, Adrianichthyidae) from Malili, Central Sulawesi, Indonesia. Copeia 106 (2): 297-304. https://doi.org/10.1643/CI-17-704

Miesen FW, Droppelmann F, Hüllen S, Hadiaty RK, Herder F (2016) An annotated checklist of the inland fishes of Sulawesi. Bonn Zoological Bulletin 64 (2): 77-106.

Teichert N, Valade P, Grondin H, Trichet E, Sardenne F, Gaudin P (2016) Pelagic larval traits of the amphidromous goby Sicyopterus lagocephalus display seasonal variations related to temperature in La Réunion island. Ecology of Freshwater Fish 25 (2): 234-247. https://doi.org/10.1111/eff.12205

Tweedley JR, Bird DJ, Potter IC, Gill HS, Miller PJ, O'Donovan G, Tjakrawidjaja AH (2013) Species compositions and ecology of the riverine ichthyofaunas in two Sulawesian islands in the biodiversity hotspot of Wallacea. Journal of Fish Biology 82 (6): 1916 1950. https://doi.org/10.1111/jfb.12121

Watanabe S, Iida M, Kimura Y, Feunteun E, Tsukamoto K (2006) Genetic diversity of Sicyopterus japonicus as revealed by mitochondrial DNA sequencing. Coastal Marine Science 30 (2): 473-479. http://doi.org/10.15083/00040741

Watson RE, Kottelat M (2006) Two new freshwater gobies from Halmahera, Maluku, Indonesia (Teleostei: Gobioidei: Sicydiinae). Ichthyological Exploration of Freshwaters 17 (2): 121-128.

Whitten AJ, Mustafa M, Henderson GS (1987) The ecology of Sulawesi. Gadjah Mada University Press, Yogyakarta, Indonesia, $777 \mathrm{pp}$. 